\title{
Significance of bile-duct changes in schistosomiasis
}

\author{
Significado das lesões dos ductos biliares na esquistossomose
}

\author{
Ludmila Oliveira $^{1}$ and Zilton A. Andrade ${ }^{2}$
}

\begin{abstract}
Lesions involving the intra-hepatic biliary ducts in schistosomiasis have been reported in the literature, both in mice and man, but there are no data concerning their quantitative, evolutionary or post curative chemotherapeutic aspects on record. In order to obtain such data an investigation on this subject was attempted. Mice infected with 50 Schistosoma mansoni cercariae were submitted to a liver biopsy at the $9^{\text {th }}$ week post-infection, and treated with $400 \mathrm{mg} / \mathrm{bw}$ praziquantel immediately afterwards. Infected and non-infected controls were submitted to the same procedures. By 19 weeks from cercarial exposure all surviving animals were sacrificed. The biliary ducts were counted on histological sections and the results were expressed as biliary ducts/portal spaces. This quantitative evaluation was compared with that from normal controls and revealed hyperplasia as the main biliary duct change $(p<0.007)$ in schistosomiasis. Hyperplastic changes underwent only mild partial and not statistically significant regression after specific chemotherapy $(p>0.05)$. Infected and untreated animals presented ductal changes that did not differ from those of the treated group. Measurements of serum bilirrubin (total and direct), and gamma-glutamyltranspeptidase $(\gamma-G T)$ did not reveal significant differences when animals from the several groups were compared. Thus, bile ducts exhibit a proliferative response in relation to neighboring S. mansoni injury to portal areas, but although these lesions are histopathologically impressive, they lack a functional or prognostic significance.
\end{abstract}

Key-words: Schistosoma mansoni. Hepatic schistosomiasis. Bile ducts.

\section{RESUMO}

A literatura registra que os ductos biliares intra-hepáticos são lesados no curso da esquistossomose, tanto experimental como humana, mas não existe avaliação quantitativa de tais lesões nos vários estágios da infecção, nem da sua repercussão funcional ou do seu comportamento frente a tratamento curativo da parasitose. Para avaliar estes parâmetros, os camundongos com infecção por 50 cercárias do Schistosoma mansoni foram submetidos à biópsia hepática na fase recente da infecção (9 semanas) e, em seguida, os animais foram tratados com praziquantel ( $400 \mathrm{mg} / \mathrm{kg}$ pc). Controles infectados e não infectados foram incluídos. Durante a $19^{a}$ semana pós-infecção todos os animais foram sacrificados. A contagem dos ductos biliares revelou a presença de uma hiperplasia ductal nos animais infectados em relação aos controles intactos ( $p<0,007)$, a qual não regrediu significativamente após a terapia antiparasitária $(p>0,05)$. Animais infectados e não tratados exibiram lesões ductais que não diferiram quantitativa ou qualitativamente dos tratados. As concentrações séricas de bilirrubinas (total e direta) e gama-glutamil-transpeptidase ( $\gamma$-GT) não mostraram diferenças significativas para os animais dos vários grupos. Em conclusão, os ductos biliares mostram uma resposta proliferativa face às alterações de vizinhança provocadas pelo $\mathrm{S}$. mansoni nos espaços porta mas, embora bem evidentes histopatologicamente, tais lesões carecem de significado funcional ou prognóstico.

Palavras-chaves: Schistosoma mansoni. Esquistossomose hepática. Ductos biliares.

References to hyperplastic and degenerative changes involving the intra-hepatic bile ducts of patients with hepatosplenic schistosomiasis have appeared in the literature since long ago ${ }^{2}$. However, only in 1979, Bedi and Isseroff ${ }^{4}$ called particular attention to this problem by describing biliary changes in Schistosoma mansoni-infected mice. They compared the changes to those found in fascioliasis and attributed them to the production of large quantities of proline by the worms. Ten years later, Vianna et $\mathrm{al}^{12}$ returned to this subject and described bile-duct histological changes in

\footnotetext{
1. Universidade Federal da Bahia, Salvador, BA. 2. Laboratory of Experimental Pathology, Gonçalo Moniz Research Center, FIOCRUZ, Salvador, BA. Supported by PAPES III, Oswaldo Cruz Foundation and PRONEX.

Address to: Dr. Zilton A. Andrade. Centro de Pesquisas Gonçalo Moniz/FIOCRUZ. Rua Valdemar Falcão 121, 40295-001 Salvador, BA, Brasil.

e-mail: zilton@cpqgm.fiocruz.br

Recebido para publicação em 30/12/2004

Aceito em 21/8/2005
} 
patients with hepatosplenic schistosomiasis, focusing on epithelial hyperplasia and mucoid production, which they considered as non-specific alterations.

Apart from primary diseases that affect the intra-hepatic bileducts, such as primary biliary cirrhosis, primary sclerosing cholangitis, auto-immune cholangitis, etc, the biliary ducts may be secondarily involved in the course of several chronic inflammatory diseases of the liver. In some of them (chronic rejection of transplants, chronic viral hepatitis) the biliary ductal changes are of great concern, since sometimes they do indicate an ominous prognosis ${ }^{7}$. In other instances, the ductal changes may be non-specific, with little repercussion upon the course of the primary disease. But, due to the importance of such structures, which are very sensitive to inflammatory portal changes in their vicinity, the prognostic significance and functional repercussion of their lesions has always aroused interest and demanded investigation. The present work makes a quantitative estimation of the intra-hepatic bile-duct histological changes found in $S$. mansoni-infected mice during different stages of the infection, evaluates their response to curative chemotherapy and their functional significance.

\section{MATERIAL AND METHODS}

Animals and experimental groups. Forty-six female Swiss mice, weighing 18-22g, were maintained in large boxes in a well-ventilated room, with free access to water and to a commercial balanced diet. They were separated into 4 groups, as follows:

Group 1. Eighteen Schistosoma mansoni-infected animals submitted to a liver biopsy nine weeks after cercarial exposure and, immediately afterward, treated with praziquantel.

Group 2. Eighteen non-treated-S. mansoni-infected animals serving as infection controls.

Group 3. Five non-infected and non-treated mice serving as intact controls.

Group 4. Five non-infected animals submitted to praziquantel treatment under the same schedule as for Group 1, serving as treatment controls.

Infection and procedures. Infection was accomplished by the transcutaneous route, with 50 freshly eliminated cercariae obtained from Laboratory raised and infected Biomphalaria glabrata, from the Feira de Santana stocks ${ }^{3}$. Ten weeks later, with the infected mice eliminating viable parasite eggs in stools, a liver biopsy was performed in the animals from all groups. The abdomen was opened at the shaved midline under aseptic conditions and general anesthesia, and a fragment of the liver of approximately $0.30 \mathrm{~g}$ was tied and removed. Recovery from surgery was uneventful.

Ten weeks later all the experimental animals were anesthetized and sacrificed by severing of the abdominal aorta. The liver was removed. Viable schistosome eggs were found in smash preparations made from the liver and intestines of infected mice, but none from the praziquantel- treated sub-group. By the end of this study, 4 animals from Group 1, 12 from Group 2, and one each from Groups 3 and 4 had died spontaneously, and were discarded.

Treatment. Praziquantel (Farmanguinhos, FIOCRUZ, Rio de Janeiro, Brazil) was administered by gavage, $400 \mathrm{mg} / \mathrm{Kg}$ body weight. The total dose per animal was suspended in $0.4 \mathrm{ml}$ of saline and administered in two halves, one in the morning and another late in the afternoon. Treatment was well tolerated.

Histology and bile-duct counting. Pieces of the livers removed either by biopsy or necropsy, were fixed in phosphatebuffered $10 \%$ formalin, $\mathrm{pH} 7.2$, and embedded in paraffin. Sections were stained with hematoxylin and eosin. Bile-ducts present in large and medium-sized portal spaces were all counted in several slides from each case, and recorded as bile-ducts/portal spaces. Every lumen delimited by epithelium was counted, regardless of size or shape. The number obtained by the division of the number of ducts per portal spaces in each case was taken for comparative purposes. All small, medium or large-sized biliary ducts present in portal spaces were individually examined, counted and registered. Small ductules or ductular cells, usually present near the parenchymal border, were discarded from counting. They did not appear to be particularly affected. Counting was performed twice and blindly from coded slides, under a 40X objective.

Functional evaluation: blood was collected from the tail vein at the time of biopsy and from the axillary plexus during autopsy, from all the animals. After blood coagulation and centrifugation, the serum was collected and stored at $-70^{\circ} \mathrm{C}$. Levels of the bilirrubins (total and direct), and gamma-glutamyltranspeptidase $(\gamma-\mathrm{GT})$ were measured by means of a Johnson \& Johnson VITROS $^{\circledR} 250$ analyzer at the Otávio Mangabeira Hospital, Salvador, BA. by courtesy of Dr. Marilda Casela.

Statistical Analysis. Statistical analysis was made by the Kruskal-Wallis method.

\section{RESULTS}

Infection with $S$. mansoni was successful and uniform, presenting the usually expected hepatic lesions of schistosomiasis in all exposed mice. The counting of duct lumina in relation to portal spaces showed a significant increase in the number of ducts when a comparison was made with early infected animals as opposed to intact controls, (Figure 1). This ductal hyperplasia was similarly observed in chronically infected mice and was not particularly affected by the curative treatment of schistosomiasis (Figure 2). Functional evaluation of the biliary system did not reveal statistically significant differences when the several groups were compared (Table 1).

During the early stage of the infection, large eosinophilrich granulomas, centered by mature schistosome eggs were scattered throughout the liver sections. The portal spaces were enlarged by edema and a rich cellular infiltration, with predominance of polymorphonuclear eosinophils, lymphocytes and macrophages, besides a few periovular granulomas (Figure 3C). During the chronic stage, the portal 


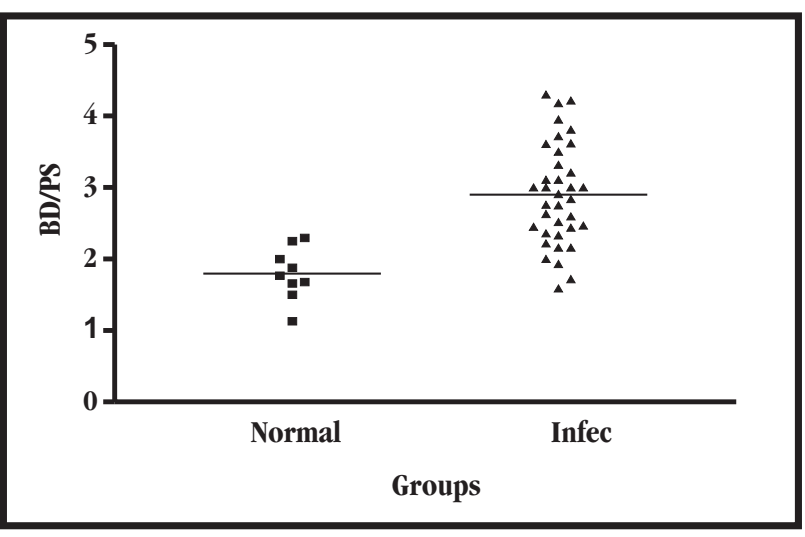

Figure 1 - Counting of biliary ducts (bile ducts/portal spaces) in mice with 9-week Schistosoma mansoni infection (Infec) as compared to normal controls (Normal). $(p<0.007)$.

Table 1- Evaluation of hepatic functional serum factors from several groups of mice infected with Schistosoma mansoni, during early and late infection and after specific treatment, as compared to intact controls.

\begin{tabular}{lrrc}
\hline Groups & \multicolumn{1}{c}{$\gamma$ - GT } & Total bilirrubin & Direct bilirrubin \\
\hline Intact controls $(\mathrm{N}=4)$ & $10.25 \pm 5.58$ & $1.35 \pm 0.62$ & $1.35 \pm 0.62$ \\
Recent infect 10 weeks $(\mathrm{N}=14)$ & $7.33 \pm 4.04$ & $0.84 \pm 0.8$ & $0.84 \pm 0.8$ \\
Chronic infect 19 weeks $(\mathrm{N}=6)$ & $5.33 \pm 0.56$ & $0.7 \pm 0.35$ & $0.7 \pm 0.35$ \\
Praziquantel treated $(\mathrm{N}=4)$ & $7.3 \pm 3.38$ & $1.02 \pm 0.77$ & $1.02 \pm 0.77$ \\
\hline
\end{tabular}

$\mathrm{p}>0.05$

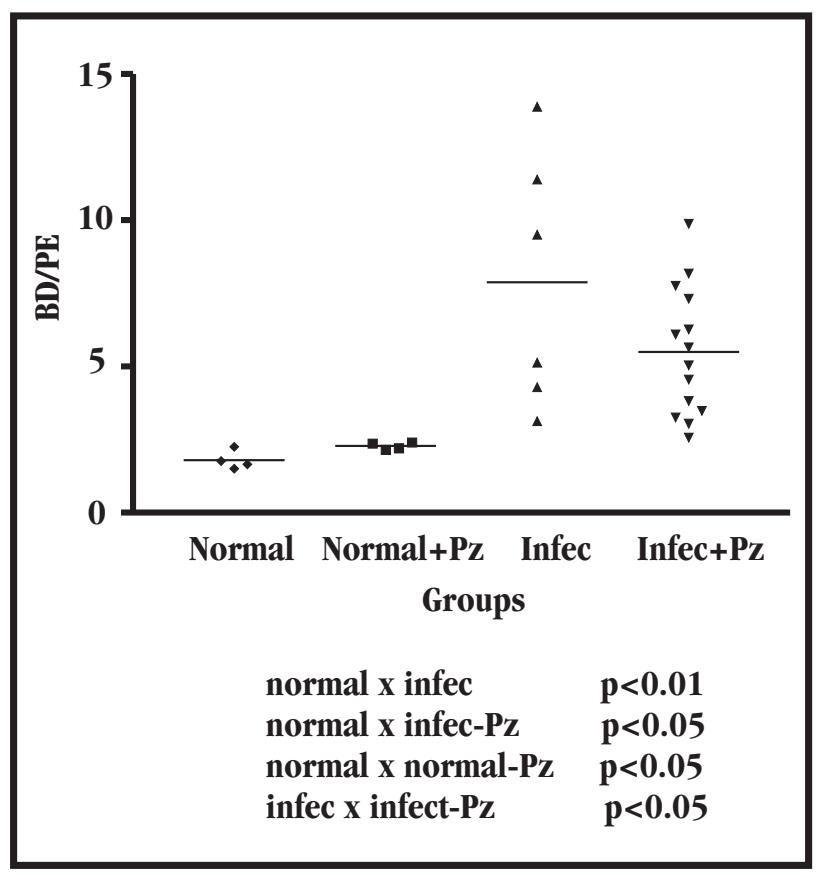

Figure 2 - Counting of bile-ducts (number ducts/portal spaces) in mice with 19 week-old Schistosoma mansoni infection, either treated with praziquantel $(\mathrm{Pz}) 10$ weeks earlier or non-treated, in comparison also with normal noninfected mice, either treated with praziquantel or not.

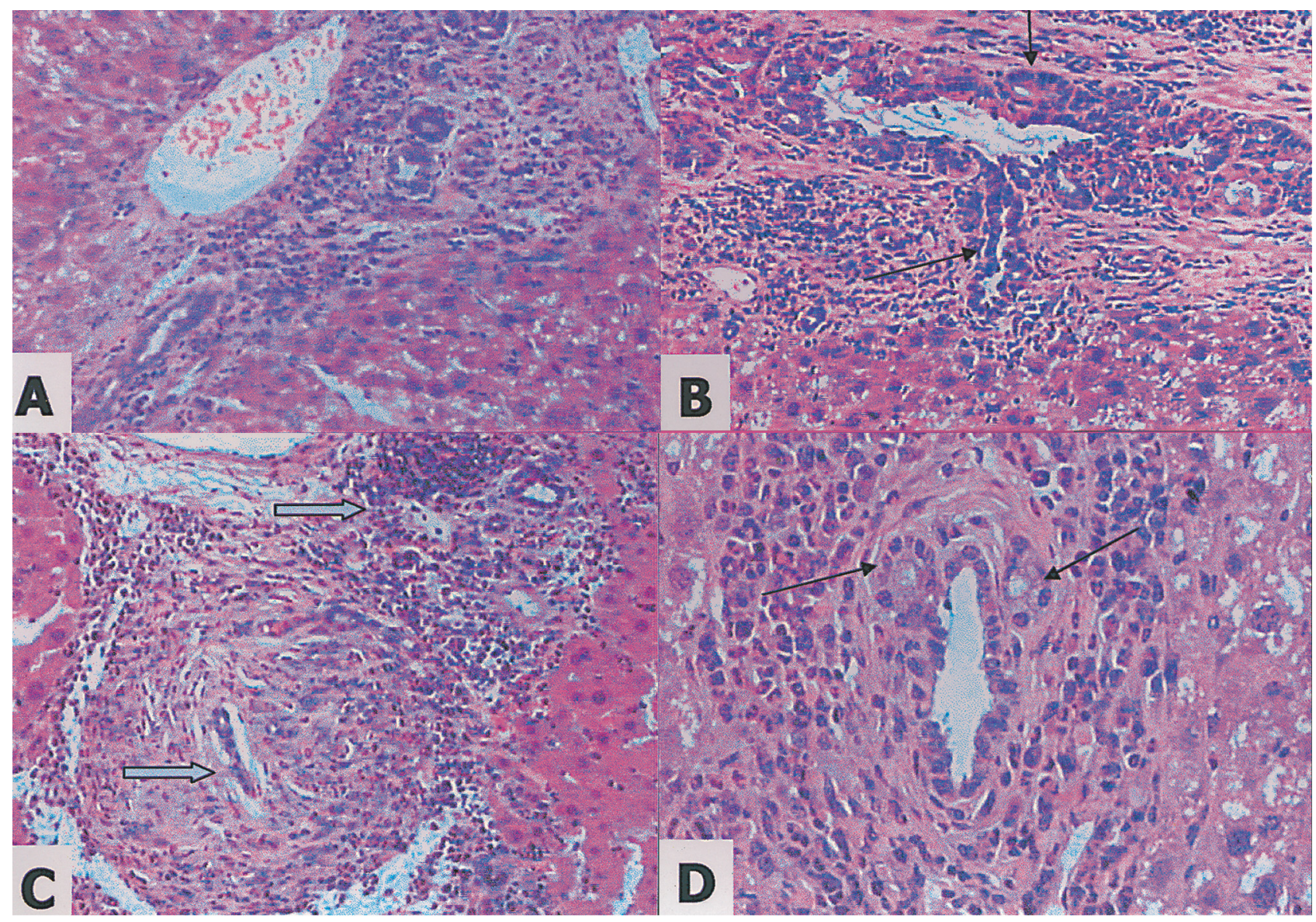

Figure 3 - Bile duct changes observed in the liver of mice with early Schistosoma mansoni infection (9 weeks post infection). In A, portal inflammation and ductal proliferation are depicted in all micrographs. In $B$ lateral buddings of the biliary epithelium create secondary ductal and ductular lumina (arrows). In $C$, proliferating ducts appear inside the periovular granuloma (arrows), and in $D$, a medium-sized duct gives origin to two new small ducts that appear lined with a secretory high colunar epithelium (arrows). $\mathrm{H} \& \mathrm{E} ; \mathrm{A}$ and $\mathrm{B}, \mathrm{X} 200 ; \mathrm{C}$ and $\mathrm{D}, \mathrm{X} 400$. 
spaces were enlarged by fibrosis and by the presence of several periovular granulomas, representing the pipe-stem picture of the murine model. Bile-duct changes were essentially similar during the two periods considered, early and late infection. They consisted of variable degrees of ductal hyperplasia, with several lateral budding or sprouting, forming tiny new lumina delimited by an epithelial layer with nuclear crowding, sometimes revealing a stratified or pseudo-stratified appearance (Figures 4A-D). Some ductal epithelia presented evidences of increased mucinous secretion (Figure 3B and D). Sometimes, ducts were seen within periovular granulomas (Figure 3C).

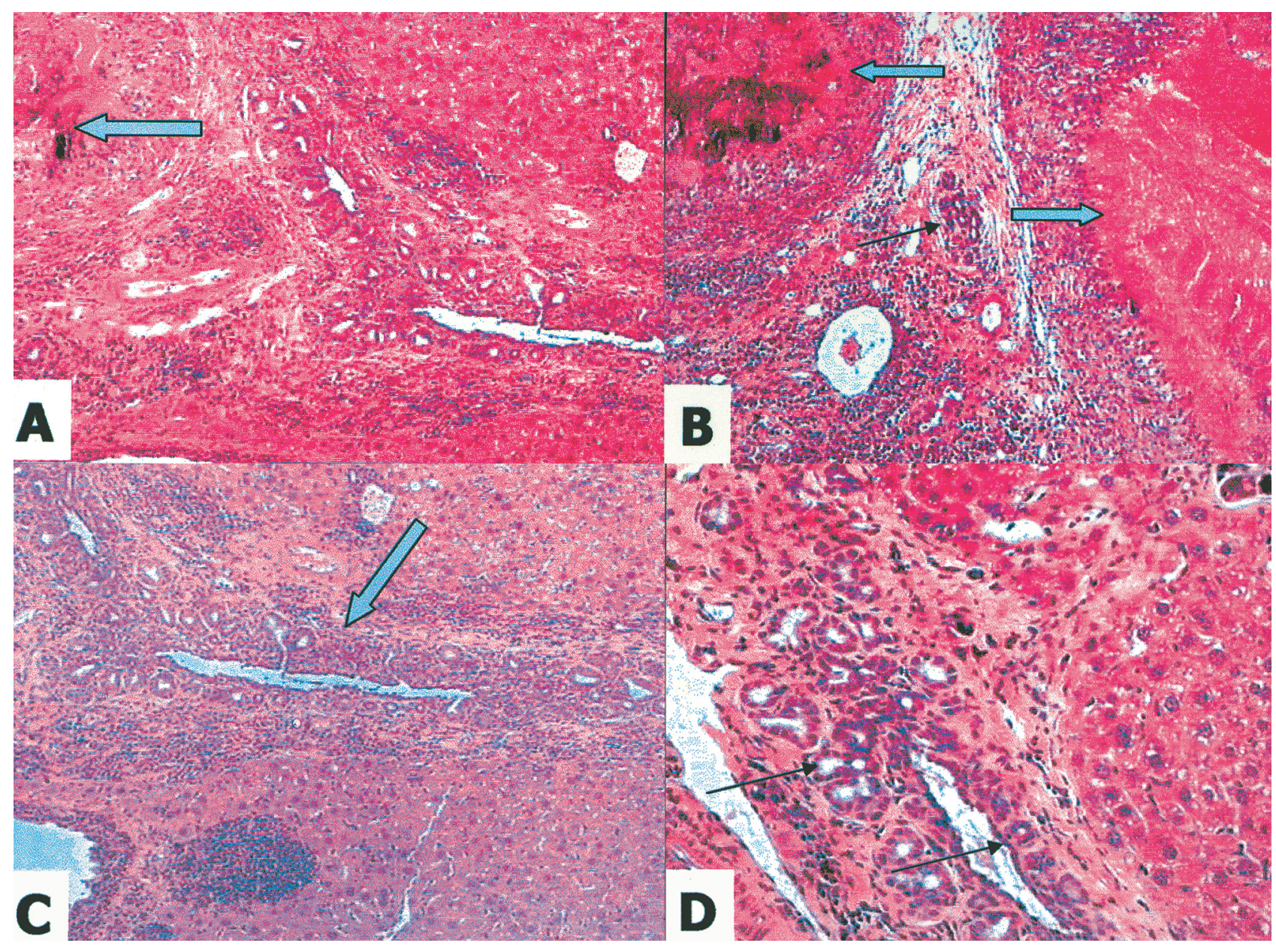

Figure 4 - Bile duct changes observed in the liver of mice with late Schistosoma mansoni infection (19 weeks post infection). A and B illustrate aspects seen in the liver of mice, 10 weeks after specific treatment of schistosomiasis with praziquantel. Arrows point to necrotic lesions caused by the death of worms. Besides foci of necrosis, there are portal fibrosis, mild chronic inflammation and extensive biliary duct proliferation (small arrows); $C$ and $D$ show similar portal changes in infected and non-treated mice. $H \& E, X 100$, except for $D, X 400$.

\section{DISCUSSION}

Bile ducts in portal spaces readily react to several stimuli generated by different pathological processes. These responses may vary in intensity and quality depending not only on etiology, but also on whether the ducts are large, medium or small ${ }^{1}$. However, irrespective of their functional counterpart, these biliary duct changes may have prognostic significance regarding the course of the main disease they appear associated with. Presence of abnormal bile duct epithelium has been described as a special feature of severe acute viral hepatitis ${ }^{9}{ }^{10}$. Proliferative and degenerative ductal alterations in chronic hepatitis B and C may correlate with a more severe clinical course ${ }^{7}$. Peculiar biliary duct changes may also point toward progression to cirrhosis, more in relation to chronic hepatitis $\mathrm{C}$, than to $\mathrm{B}^{10}$. On the other hand, during the course of chronic auto-immune hepatitis bile duct changes are frequent, but they show no relationship to the clinical evolution of the patients ${ }^{5}$. Therefore, each circumstance in which definite biliary duct alterations are present deserves particular attention. Hepatic schistosomiasis makes no exception, since changes affecting the bile ducts have already been described in $\operatorname{man}^{2}{ }^{12}$, in experimental schistosomiasis of mice ${ }^{4}$, and also in rabbits with schistosomiasis japonica ${ }^{11}$. The main change has been characterized as hyperplasia. The presence of mucinous secretion, especially highlighted by Vianna et $\mathrm{al}^{12}$, is only an additional feature of hyperplasia. Such hyperplasia is neither 
accompanied by evident morphologic signs of cholestasis, nor by serum alterations of the usual cholestatic markers. But, the present investigation demonstrated that proliferation of bile ducts in experimental schistosomiasis is an outstanding quantitative alteration that is not easily reversible after the cure of schistosomiasis. It is peculiar, because ductal hyperplasia is usually a readily reversible change, following elimination of its cause ${ }^{8}$. Even at the stage of secondary biliary cirrhosis, produced by total ligation of the main biliary duct in rats, ductal hyperplasia and fibrosis may almost totally regress following reestablishment of bile drainage 1 . Probably, during the present investigation, part of the stimulus to ductal proliferation still persisted 10 weeks after treatment, since by that time some lesions caused by dead worm disintegration were still observed to be in the process of being resorbed. Thus, changes in intrahepatic bile ducts are a constant and usually marked change of hepatic schistosomiasis. They do not seem to have a functional connotation, but one should be aware that periductal fibrosis, an accompaniment of ductal hyperplasia, is a constituent of portal "pipestem" fibrosis of man, as already demonstrated ${ }^{2}$.

\section{REFERENCES}

1. Alpini G, Mc Gill JM, La Russo NF. The pathobiology of biliary epithelia. Hepatology 35: 1256-1268, 2002.

2. Andrade ZA. Hepatic Schistosomiasis. Morphological aspects. In: Popper H, Schaffner F (eds) Progress in Liver Diseases II. Grune \& Stratton, New York, p. 228, 1965.
3. Andrade ZA, Sadigursky M. Um estudo comparativo das cepas Feira de Santana (Bahia) e Porto Rico do Schistosoma mansoni na infecção experimental do camundongo. Memórias do Instituto Oswaldo Cruz 80: 37-40, 1985.

4. Bedi AJK, Isseroff $\mathrm{H}$. Bile-duct hyperplasia in mice infected with Schistosoma mansoni. International Journal of Parasitology 9: 401-404, 1979.

5. Caja AJ, Muratori P, Muratori L, Carpenter HA, Bianchi FB. Diagnostic and therapeutic implications of bile duct injury in autoimmune hepatitis. Liver International 24: 322-329, 2004.

6. Cheever A, Lenzi JA, Lenzi HL, Andrade ZA. Experimental models of Schistosoma mansoni infection. Memórias do Instituto Oswaldo Cruz 97: 917-940, 2002.

7. Christroffersen P, Dietrichson 0, Farber V, Poulsen H. The occurrence and significance of abnormal bile duct epithelium in chronic aggressive hepatitis. Acta Pathologica et Microbiolica Scandinava 80: 294-302, 1972.

8. Medeiros MVMJ, Freitas LAR, Andrade, ZA. Differences in hepatic pathology resulting from bile duct obstruction in young and old rats. Brazilian Journal of Medical and Biological Research 21: 75-83, 1988.

9. Poulsen H, Christoffersen P. Abnormal bile duct epithelium in liver biopsies with histological signs of viral hepatitis. Acta Pathologica et Microbiolica Scandinava 76: 383-390, 1969.

10. Schmid M, Pirovino M, Altorfer J, Godal F, Bianchi L. Acute hepatitis nonA, non-B: are there any specific light microscopic features? Liver 2: 6167,1982 .

11. Tsutsumi H, Kakashima T. Pathology of liver cirrhosis due to Schistosoma japonicum. In: Yokogawa M (ed) Research in Filariasis and Schistosomiasi volume 2, p.113-129, 1972.

12. Vianna MR, Gayotto LCC, Santos TM, Ferreira Alves VA, Fukushima J, Brito T. Intrahepatic bile-duct changes in human hepatosplenic schistosomiasis. Liver 9: 100-109, 1989. 